\title{
STRATEGI KOMUNIKASI TERHADAP ANAK USIA DINI
}

\author{
Husnul Bahri \\ Dosen IAIN Bengkulu \\ Email : husnulbahri syukur@yahoo.com
}

\begin{abstract}
Communication as a process in delivering messages to achieve a goal, the main component is a communicator or source message, communicant or recipient of the message and the message itself. In the learning process for early childhood, communication should be developed with strategies tailored to the growth and development of children, one the foccus of study is the development to the language of children who will give a big influence on communication strategies against early age. The popular mistake communicators is an adults in the language of communication, and communication barriers for children should be great interest in devising communication strategies. three things that are very urgent is the use of appropriate terms, continuoust, and the presence of cues to switch themes.

Key Word : Strategi Komunikasi (communication strategy), Anak Usia

Dini (early childhood)
\end{abstract}

Abstak: Komunikasi sebagai sebuah proses dalam menyampaian pesan untuk mencapai suatu tujuan, komponen utamanya adalah komunikator atau sumber pesan, komunikan atau penerima pesan dan pesan itu sendiri. Dalam proses pembelajaran bagi anak usia dini, komunikasi harus dikembangkan dengan strategi yang disesuaikan dengan tingkat pertumbuhan dan perkembangan anak, salah satu pusat perhatian kajian adalah perkembangan bahasa anak yang akan memberikan pengaruh besar terhadap strategi komunikasi terhadap anan usia dini. Kesalahan populer komunikator yaitu orang dewasa dalam bahasa komunikasi, dan hambatan-hambatan komunikasi bagi anak harus menjadi perhatian yang besar dalam menyusun strategi komunikasi.tiga hal yang sangat urgen yaitu penggunaan istilah yang tepat, berkesinambungan, dan adanya aba-aba untuk berpindah tema.

Kata kunci: strategi komunikasi, anak usia dini.

\section{Pendahuluan}

Dalam konseptual interaksi bahwa komunikasi memiliki peran yang utama untuk mencapai tujuan, khususnya dalam konteks pembelajaran maka komunikasi menjadi sebuah strategi yang harus mendapatkan perhatian sebaik-baiknya. Tanpa komunikasi yang baik dan benar tidak akan ada tercipta suasana yang bahagia, demikian halnya tanpa adanya percakapan yang efektif tidak akan ada kesepahaman untuk mencapai sebuah kesepakatan. Sebagai ilustrasi dikeseharian dalam suatu rumah tangga, kita menemukan kondisi dimana Ibu dan ayah tidak satu makna dalam perintah seperti sang ayah berkata "tidak" dan sang ibu berkata "ya". Atau sebaliknya, maka informasi yang harus diterima sang anak akan sulit, hal ini harus diperjelas dengan kejelasan berkomunikasi yang baik dan benar agar sang anak dapat mempunyai pemahaman yang be- nar terhadap informasi yang diterimanya.

Sebagaimana kita ketahui bahwa sesungguhnya pendidikan yang utama dan pertama bagi anak usia dini berada di rumah bersama orang tua yaitu ayah dan ibu. Indikatornya adalah : (1) orang tua merupakan orang yang paling bertanggungjawab terhadap perkembangan anak-anaknya, (2) orang tua merupakan orang yang pertama berinteraksi dengan anak-anaknya sebelum mereka berinteraksi dengan orang lain, (3) lingkungan keluarga merupakan lingkungan terdekat yang sangat berpengaruh terhadap kepribadian anak, dan (4) waktu yang dimiliki oleh anak lebih banyak dihabiskan di rumah bersama orangtuanya . Dengan demikian pemberian asah, asih dan asuh kepada anak usia dini menjadi tanggungjawab utama bagi orangtuanyayaitu ayah dan ibunya.

Sarana komunikasi yang dibangun yaitu bahasa 
adalah mampu membangun keterampilan berkomunikasi, keterampilan menyampaikan pendapat, gagasan, dan pandangan dalam menyikapi suatu persoalan yang dihadapi dalam kehidupan. Keterampilan seperti itu tentu sangat dibutuhkan dalam proses tumbuh kembang anak usia dini.bahasa juga merupakan alat berpikir, Oleh karena itu, melalui kemampuan berbahasa, berbagai persoalan yang dihadapi dapat dipahami, disikapi, dan dicerna dengan baik sehingga dapat menambah kematangan berpikir atau kematangan intelektual seseorang. Berkenaan dengan itu, kemampuan berkomunikasi yang tinggi dan daya pikir yang kritis dalam menghadapi setiap tantangan pada gilirannya juga dapat melahirkan generasi yang kreatif dan inovatif.

Komunikasi merupakan kunci sukses hubungan antara orang tua dengan anak-anaknya. Bentuk komunikasi verbal dengan kata-kata maupun komunikasi non verbal seperti pelukan, ciuman, sentuhan, dll merupakan bentuk komunikasi yang perlu dipupuk dan dilatih kepada anak sejak anak usia dini. Sehingga sampai kapanpun "komunikasi kasih sayang" dari kedua orang tua kepada anak-anaknya dapat terus berlangsung, tanpa anak merasa malu, terganggu dan lain-lain.Proses belajar komunikasi anak merupakan kolaborasiantara kedua orang tua dengan anak-anaknya, dan kolaborasi tersebut dapat dimulai sejak anak masih 0 tahun. Masa inilah merupakan fondasibagi seorang anak untuk membekali dirinya dalam menyongsong dan menjalani kehidupan dimasa depannya. Proses pembelajaran komunikasi ini akan mematangkan pembelajaran etika, nilai (value), kepribadian, dansikap agar mereka benar-benar menjadi sosok penerus bangsa yang berperilaku dan berkepribadian luhur seperti apa yang diamanatkan oleh para pejuang negeri tercinta ini.Komunikasi yang baik antara orang tua dengan anak, sangat membantu anak memahami dirinya sendiri, perasaannya, pikirannya, pendapatnya dan keinginan-keinginannya. Anak dapat mengidentifikasi perasaannya secara tepat sehingga membantunya untuk mengenali perasaan yang sama pada orang lain.

Setiap orang tua dan pendidik pasti menginginkan yang terbaik bagi anaknya, tapi kadang harapan itu terkendala oleh komunikasi dalam pola asuh yang diterapkan oleh orang tua sejak anak tersebut berusia dini. Dengan mengetahui betapa pentingnya komunikasi terhadap anak usia dini, maka ka- jian ini mejadi sangat penting untuk disusun dan diharapkan dapat dijadikan sebagai salah satu referensi bagi setiap orang tua atau orang dewasa dalam mendidik anak. Dengan bekal pengetahuan strategi berkomunikasi, maka orang tua dapat mewujudkan dan membimbing anak-anaknya menjadi anak yang handal dan berkualitas serta siap untuk menghadapi kehidupan yang semakin kompleks.

Menjadi permasalahan kajian ini adalah "Bagaimanakah strategi komunikasi terhadap anak usia dini?".

\section{Pembahasan}

Komunikasi pada dasarnya merupakan kegiatan penyampaian pesan. Proses tersebut melibatkan dua pihak yang berkomunikasi yang masing-masing bertujuan membangun suatu makna agar keduanya memahami atas apa yang sedang dikomunikasikan. Komunikasi dapat diartikan sebagai suatu proses pembentukan, penyampaian, penerimaan dan pengolahan pesan yang terjadi di dalam diri seseorang dan atau di antara dua atau lebih dengan tujuan tertentu. Pada komunikasi lisan, terdapat istilah yang menjadi prasyarat utama, yaitu interaksi. Interaksi bertujuan mendapatkan makna yang sama-sama dimengerti oleh pihak-pihak yang berkomunikasi. ${ }^{1}$

Bagaimana cara mengoptimalkan komunikasi berkenaan dengan interaksi pada anak usia dini? Seyogyanya hal ini kita mulai dari lingkungan terdekat anak yaitu keluarga. Melalui pola komunikasi yang tepat seiring dengan kemampuan berbahasa orang tua yang akan ditrasfer pada anak lewat komunikasi yang efektif, maka segala hal positif berkenaan dengan tumbuhkembang anak yang sesuai harapan akan terpenuhi.

Beberapa teori pembelajaran bahasa anak dapat dijadikan bahan acuan analisis penyusunan strategi komunikasi terhadap anak usia dini sesuai dengan tingkatan pertumbuhan dan perkembangannya. Perkembangan strategi komunikasi berawal dari perkembangan bahasa anak. Bahasa anak awalnya berkembang secara alami. Proses ini dikenal dengan pemerolehan bahasa. Melalui interaksi dengan lingkungan anak memperoleh pengalaman yang memberi sumbangan terhadap perkembangan ba-

'Brown, H. Douglas. 1994. Principles of Language and Teaching. Third Edition New Jersey Prentice Hall Regents 
hasa. Di samping itu, bahasa anak juga dapat distimulasi dengan berbagai cara. Stimulasi tersebut dikenal dengan pembelajaran yang direalisasi dalam bentuk kegiatan-kegiatan belajar atau bermain. Agar pendidik dapat memberikan stimulasi yang tepat, pendidik perlu memiliki pengetahuantentang perkembangan bahasa.

Ada tiga teori dasar yang dapat digunakan untuk memahami perkembangan bahasa anak. Ketiga teori tersebut dikemukakan berikut ini:

\section{Teori Behavioristik (Teori Perilaku) dari Skinner}

Teori dalam aliran behavioristik yang diprakarsai oleh BF. Skinner yang menyatakan bahwa lingkungan memberi pengaruh utama bagi perkembangan bahasa anak. ${ }^{2}$ Oleh karenanya orang tua dan pendidik perlu aktif mengajak anak berbicara dan memberi contoh penggunaan bahasa yang baik. Teori perilaku juga percaya bahwa agar anak berhasil dibutuhkan penguatan. Bentuk penguatan khususnya adalah pujian atau barang-barang sederhana. Anak perlu diberi contoh ucapan sehingga anak dapat meniru ucapan tersebut. Atas keberhasilan anak mengulangi contoh yang diberikan, perlu diberi penguatan dan imbalan yang segera diberikan seperti 'bagus', pinter, diberi permen atau yang lainnya yang setimpal. Teori ini menekankan bahwa dalam perkembangan bahasa anak usia dini, orangtua dituntut untuk memberikan stimulasi, seperti aktif mengajak anak berbicara dan bercakap-cakap agar pencapaian kemampuan berbahasa anak maksimal.

\section{Teori Nativistik dari Chomsky}

Noam Chomsky mengkritik teori yang dikemukakan Skinner. Ia menyatakan bahwa perkembangan bahasa anak tidak ditentukan oleh lingkungan semata. Faktor genetik sangat menentukan perkembangan bahasa anak. ${ }^{3}$ Menurut Noan Chomsky kemampuan bahasa anak terbentuk mulai dari konsepsi. Dengan kata lain, sejak lahir anak telah memiliki kemampuan berbahasa. Kemampuan tersebut dikenal dengan Language Advice Device

${ }^{2}$ Hurlock Elizabeth B. 2005 Perkembangan anak Jilid 1. Jakarta. Penerbit Erlangga..
(LAD). Chomsky juga memperkenalkan Universal Grammar dalam kemampuan bahasa anak. Ini merupakan kelemahan dan sumber kritik atas teorinya Chomsky. Selanjutnya Chomsky juga menyatakan bahwa belajar bahasa sebaiknya sebelum usia sepuluh tahun. Kemampuan yang terbentuk pada saat dalam kandungan akan teraktualisasi atau berkembangan dengan didukung oleh faktor biologis dan faktor lingkungan setelah anak lahir. Untuk itu, Noam Chomsky menyatakan faktor lingkungan juga sangat berperan dalam perkembangan bahasa anak disamping kesiapan faktor biologis. Ada kemampuan yang tidak mungkin dimiliki anak, walau lingkungan memberi stimulasi yang maksimal kalau kondisi biologis belum siap untuk mencapai kemampuan tersebut. Misalnya, pengucapan huruf 'g' tidak mungkin dimiliki sebelum alveolenatal matang untuk berfungsi.

Teori ini Mengutarakan bahwa bahasa sudah ada di dalarn diri anak. Pada saat seorang anak lahir, dia telah memiiiki seperangkat kemampuan berbahasa yang disebut Tata Bahasa Umum" atau 'Universal Grammar'. Teori ini mengatakan bahwa meskipun pengetahuan yang ada di dalam diri anak tidak rnendapatkan banyak rangsangan, anak akan tetap dapat mempelajarinya. Anak tidak sekedar meniru bahasa.yang dia dengarkan, tapi ia juga mampu menarik kesimpulan dari pola yang ada, hal ini karena anak memiliki sistem bahasa yang disebut Perangkat Penguasaan Bahasa. Teori Nativistik juga memberikan pengetahuan bahwa keterampilan bahasa juga dipengaruhi oleh kematangan fisik anak, misalnya kematangan organ-organ bicara. Oleh karena itu, pendidik dalam dalam memberikan stimulasi perlu memperhatikan kesiapan anak. Teori ini juga memberikan wawasan bahwa anak akan belajar bahasa dengan cepat sebelum usia 10 tahun. Artinya, pembelajaran bahasa lebih baik diberikan sejak dini, karena lebih dari usia 10 tahun anak akan mengalami kesulitan.

\section{Teori Konstruktivisme dari Piaget, Vygotsky, Gardner \\ Perkembangan kognisi dan bahasa dibentuk}


dari interaksi dengan orang lain. ${ }^{4}$ Dengan berinteraksi dengan orang lain, maka pengetahuan, nilai dan sikap anak akan berkembang. Anak memiliki perkembangan kognisi yang terbatas pada usia-usia tertentu, tetapi melalui interaksi sosial, anak akan mengalarni peningkatan kemampuan berpikir.

Pengaruh pada pembelajaran. Anak akan dapat belajar dengan optimal jika diberikan kegiatan, Sementara anak melakukan kegiatan, anak perlu didorong untuk sering berkomunikasi. Adanya anak yang lebih tua usianya atau orang dewasa yang mendampingi pembeiajaran dan mengajak bercakap-cakap akan menolong anak menggunakan kemampuan berbahasa yang lebih tinggi. Jika anak mengalami kesulitan, peran orang dewasa yang tepat akan membantu anak memecahkan persoalan sehingga anak dapat belajar sesuatu dari peristiwa tersebut. Karena itu pendidik perlu menggunakan metode yang interaktif, menantang anak untuk meningkatkan pembeiajaran dan menggunakan bahasa yang berkualitas

\section{Kendala-Kendala Dalam Komunikasi Anak}

Komunikasi anak juga sangat dipengaruhi oleh beberapa faktor sehingga anak mudah untuk berkomunikasi dengan orang lain. Faktor-faktor itu adalah: 5

a. Kesehatan, anak yang sehat lebih mudah berkomunikasi daripada anak yang kurang sehat. Anak yang sehat memiliki motivasi yang kuat untuk menjadi anggota kelompok sosialnya (teman sejawat) dan berkomunikasi dengan anggota kelompok tersebut.

b. Kecerdasan, anak yang cerdas lebih mudahberkomunikasi daripada anak yang kurang cerdas. Anak yang cerdas mempunyai rasa percaya diri yang besar dan tidak ada ketakutan untuk tidak diterima oleh anggota kelompoknya atau teman sejawatnya.

c. Keadaan sosial ekonomi, anak dari tingkat sosial ekonomi lebih tinggi punya kecenderungan untuk mudah berkomunikasi karena anak sering didorong untuk mengungkapkan perasaannya. Anak juga merasa aman dan terpenuhi jika mengungkapkan perasaan dan keinginanya.

${ }^{5}$ Zahroh. 2002. Komunikasi dalam Pengasuhan. Kementerian Pendidikan dan Kebudayaan d. Jenis kelamin, anak laki-laki mempunyai kecenderungan lebih susah berkomunikasi dibandingkan dengan anak perempuan. Kalimat dalam komunikasi anak laki-laki lebih pendek-pendek dan tata bahasanya kurang betul dibandingkan dengan anak perempuan. Kosa kata yang diucapkan anak laki-laki lebih sedikit dan pengucapannya kurang tepat dibandingkan dengan anak perempuan.

e. Keinginan berkomunikasi, semakin kuat keinginan anak berkomunikasi dengan orang lain atau teman sejawat semakin mudah anak tersebut berkomunikasi. Anak akan menyisihkan waktu dan kesempatan untuk berkomunikasi dangan temannya.

f. Dorongan, semakin anak didorong berkomunikasi dengan yang lain, semakin mudah anak berkomunikasi. Semakin sering anak diajak bicara, ditanya, dan diajak komunikasi baik dalam keluarga maupun dalam lingkungan semakin anak senang berkomunikasi karena merasa diterima keberadaanya.

g. Jumlah dalam keluarga, semakin kecil anggota keluarga anak tersebut semakin mudah untuk berkomunikasi, karena kesempatan berkomunikasi dengan yang lain semakin besar. Orang tua lebih bisa menyisihkan waktu untuk berkomunikasi dengan anak sehingga kemampuan komunikasi anak semakin baik.

h. Urutan kelahiran, anak yang lahir pertama mempunyai kecenderungan untuk lebih mudah berkomunikasi dengan orang tuanya ketimbang anak yang lahir kemudian. Anak pertama biasanya mendapat limpahan kasih sayang dan waktu yang lebih daripada anak yang kedua, dengan limpahan kasih sayang dan waktu ini anak merasa diperhatikan dan diterima oleh orang tuanya.

i. Metode pelatihan anak, anak yang diasuh secara otoriter yang menekankan bahwa anak harus dilihat dan bukan didengar mempunyai hambatan komunikasi. Seharusnya pelatihan komunikasi anak yang diterapkan adalah memberikan keleluasaan dan demokratis serta mendorong anak untuk belajar lebih.

j. Kelahiran kembar, anak yang lahir kembar umumnya terlambat dalam perkembangan komunikasinya, karena mereka lebih banyak bergaul 
dengan saudara kembarnya. Anak kembar punya kecenderungan miskin logat dan melemahkan motivasi untuk komunikasi.

k. Hubungan dengan teman sejawat, anak-anak semakin banyak berhubungan dengan teman sebayanya, maka lebih mudah berkomunikasi. Anak-anak semakin punya motivasi untuk bisa diterima sebagai anggota kelompok sebaya bila mampu berkomunikasi dengan baik.

1. Kepribadian, anak yang dapat menyesuaikan diri dengan baik cenderung mempunyai kemampuan untuk berkomunikasi lebih baik. Kemampuan berkomunikasi seringkali dijadikan acuan anak mempunyai kesehatan mental yang bagus apa tidak (Hurlock, 2005).

\section{Penghambat Komunikasi Anak}

Anak-anak usia dini adalah manusia yang utuh tapi belum sempurna secara mental dan pikirnya. Perasaan anak sudah ada sejak lahir dan semakin tumbuh kembang semakin sempurna perasaan anak.Terkadang orang tua meniadakan perasaan dan pikir anak ini sehingga menghambat komunikasi anak terhadap orang tuanya.Kebutuhan dasar anak adalah didengarkan, dimengerti, dihargai dan dipahami perasaannya.Sedang selama ini orang tua banyak yang menganggap bahwa orang tualah yang harus didengar. Anak-anak seringkali belum mampu mengatakan apa yang dirasakan dan diinginkan karena keterbatasan kosa kata, maka anak lebih banyak menggunakan bahasa tubuh untuk ekspresikan perasaan dan pikiranya.

Hambatan-hambatan komunikasi anak terhadap orang tua maupun teman sejawatnya adalah sering orang tua tidak bisa membaca bahasa tubuh anak-anak dan tidak bisa memahami perasaan anak serta 12 gaya komunikasi populer yang dilakukan orang tua. Pemahaman perasaan anak ini kadang memang susah diartikan, misalnya anak pulang dari sekolah sambil lesu dan tegang. Sampai rumah langsung bilang "ulanganku jelek dan temen-temen meledeki aku". kadang orang tua hanya memandang saja dan bilang "gitu saja lemes, makanya belajar". atau anak kelihatan lemes dan tidak bergairah, kadang orang tua hanya bilang "tuh kan sudah dibilangi, jangan lari-lari, sakitkan sekarang" . anak sebenarnya tidak butuh diingatkan atau dimarahi seperti itu, tetapi butuh pelukan dan kasih sayang, butuh ditenangkan. Orang tua seharusnya mema- hami bahasa tubuh anak sehingga bisa memahami perasaan anak agar komunikasi antara anak dan orang tua bisa berjalan wajar dan ank tidak terkendala dalam berkomunikasi.

Hambatan yang paling besar komunikasi anak adalah gaya-gaya populer orang tua dalam berkomunikasi. ${ }^{6}$ Yaitu :

\section{Memerintah}

Tujuan orang tua memerintah adalah orang tua ingin mengendalikan masalah dengan cepat dan praktis. Pesan yang ditangkap anak adalah mereka harus patuh, tidak boleh membantah dan anak tidak punya pilihan lain. Dengan komunikasi model seperti ini anak jadi terbiasa tidak mau berkomunikasi karena dalam dirinya ada anggapan bahwa berkomunikasipun akan percuma karena tidak akan dindengar oleh orang tuanya.

2. Menyalahkan

Tujuan orang tua menyalahkan adalah orang tua ingin menunjukan kesalahan anak sehingga tidak diulang kembali, tetapi pesan yang ditangkap anak adalah anak merasa tidak pernah benar dan baik.Dengan komunikasi seperti ini anak menjadi tidak mau berkomunikasi karena berkomunikasi yang benar maupun baik tetap saja merasa tidak dianggap oleh orang tuanya.

3. Meremehkan

Tujuan orang tua meremehkan adalah menunjukan ketidakmampuan anak dan merasa orang tua merasa lebih mampu, tetapi pesan yang diterima oleh anak adalah anak merasa tidak berharga dan tidak mampu.Dengan model komunikasi seperti ini anak tidak memiliki kepercayaan diri untuk berkomunikasi, karena baru mau berkomunikasi sudah dianggap tidak mampu.

\section{Membandingkan}

Tujuan orang tua membandingkan ini adalah orang tua ingin memberi motivasi dengan memberi contoh orang lain, tetapi pesan yang diterima anak adalah anak merasa tidak disayang, pilih kasih dan merasa dirinya selalu jelek. Dengan model komunikasi seperti ini anak merasa tidak berharga dan rasa percaya dirinya menjadi 
rendah.

5. Mencap

Tujuan orang tua mencap adalah ingin memberi tahu kekurangan anak, tetapi pesan yang diterima oleh anak adalah merasa anak yang seperti itu dan merasa tidak berdaya.

6. Mengancam

Tujuan orang tua mengancam adalah agar anak patuh dan menurut dengan proses yang cepat, tetapi pesan yang diterima oleh anak adalah anak merasa cemas dan mengalami ketakutan. Dengan model komunikasi seperti ini anak merasa takut untuk berkomunikasi dengan orang tuanya.

7. Menasehati

Tujuan orang tua menasehati adalah agar anak tahu mana yang baik dan mana yang buruk, tetapi pesan yang diterima oleh anak adalah orang tuanya terlalu bawel, sok tahu dan membosankan. Model komunikasi seperti ini membuat anak merasa bodoh dan tidak tahu apa-apa dibandingkan dengan orang tuanya.

8. Membohongi

Tujuan orang tua membohongi adalah agar urusan menjadi gampang dan mudah serta anak tidak bertanya-tanya lagi, tetapi pesan yang diterima oleh anak adalah semua orang dewasa tidak dapat dipercaya dan suka bohong. Komunikasi model seperti ini juga menciptakan anak suka berbohong, karena melihat orang tuanya.

9. Menghibur

Tujuan orang tua menghibur adalah agar anak tidak sedih atau kecewa, sehingga anak jadi senang dan tidak larut dalam kesedihan, tetapi pesan yang diterima oleh anak adalah anak tidak suka dihibur, karena kemarahan anak pada teman sejawat atau pada orang tua itu bersifat spontan dan cepat hilang. Jadi hiburan terhadap anak sebenarnya sangat tidak diperlukan.

10. Mengkritik

Tujuan orang tua menghibur adalah agar anaknya memperbaiki kesalahan dan meningkatkan kemampuan anak tersebut, namun pesan yang diterima anak adalah diri anak akan selalu merasa kurang dan salah. Pada dasarnya anak tidak suka dikritik karena akan kehilangan motivasi dan percaya diri.

11. Menyindir

Tujuan orang tua menghibur adalah memotivasi, mengingatkan agar tidak selalu melakukan kesalahan dengan cara menyatakan yng sebaliknya, namun pesan yang diterima anak adalah hal itu sangat menyakitkan hati dan perasaan anak.

12. Menganalisa

Tujuan orang tua menganalisa adalah orang tua mencari penyebab sisi positif dan negatif anak atau kesalahan anak dan berupaya mencegah agar tidak melakukan kesalahn yang sama lagi, namun pesan yang diterima anak adalah menganggap orang tua sok pintar dan sok tahu perasaan anak.

Dari pemahaman gaya-gaya komunikasi dalam pengasuhan yang populer ini, maka orang tua merasakan betapa pentingnya memahami bahasa tubuh anak, jadi orang tua bisa menebak suasana hati anak. Kalaupun salah menebaknya, anak akan memberikan petunjuk sampai kita bisa tahu apa yang sebenarnya dirasakan anak dan anak sendiri akhirnya mengenali perasaan apa yang dia rasakan.

\section{Strategi Komunikasi Terhadap Anak Usia Dini}

Secara ringkas, komunikasi efektif adalah adanya saling memahami apa yang dimaksud oleh si pemberi pesan (komunikator) dan yang menerima pesan (komunikan). Kajian komunikasi lisan (oral communication) sebagai bagian dari pembicaraan menitikberatkan pada pengucapan. Pada dasarnya, apa yang dikomunikasikan dalam bentuk lisan harus tersampaikan pesannya secara tepat dan benar.

Dalam menyusun strategi komunikasi yang efektif perlu diperhatikan oleh semuaunsur komunikasi yang berkomunikasi secara lisan diantaranya:

\section{a. Penggunaan Istilah}

Komunikator baik pendidik, orang dewasa ataupun guru harus memilih penggunaan istilah dengan tepat agar para komunikanyaitu pihak penerima pesan dalam hal ini anak usia dini atau anak didik lebih cepat memahami apa yang disampaikan. Sebagai contoh, ungkapan kata "mungkin, barangkali, bisa saja" dstnya, bisa berakibat salah tafsir. Bisa saja komunikator bermaksud mengatakan: bolehtetapi ia mengatakan bisa saja dalam kalimat "Bisa sajakalian membawa bekal makanan dari rumah". Hal ini akan sedikit membingungkan para komunikan atau anak didik. Para komunikan mungkin merasa ragu untuk membawa makanan. Berbeda dengan "Kalian bolehmembawa bekal makanan dari rumah". 


\section{b. Berkesinambungan}

Komunikator tentunya sudah memiliki perencanaan sebelum melakukan komunikasi terhadap komunikan. Bila dilakukan didalam proses pebelajaran maka jika tidak memiliki perencanaan yang baik, dimungkinkan apa yang menjadi sasaran pembelajaran tidak tercapai. Guru yang tidak melakukan perencanaan dengan baik akan melenceng terhadap topik yang dibicarakan. Sehingga dibutuhkan suatu presentasi yang berkesinambungan dan runtut agar mudah dipahami. Secara umum, biasanya dengan pengantar (pengenalan) terhadap suatu tema lalu masuk ke isi dan akhirnya review atau penutup. Dengan kata lain, penjelasan guru harus terfokus dan tidak menyampaikan hal-hal yang tidak penting apalagi hal yang tidak penting ini disampaikan secara berkepanjangan. Dengan demikian komunikasi diyakini akan menjadi efektif.

\section{c. Aba-abauntuk berpindah tema}

Guru harus memberikan aba-aba melalui berbagai cara yang tepat agar para siswa mengerti akan adanya topik baru yang harus dicermati. Hal ini akan menjadikan efektifnya suatu komunikasi. Siswa akan mempersiapkan diri menyimak hal-hal baru / topik baru. "Anak-anak tadi kalian sudah mempelajari kata benda dengan contoh-contohnya, sekarang kita akan membahas kata yang bermakna berbeda, namanya kata sifat, anak anak sudah siap...? Dengan ungkapan seperti ini, anak didik akanmenyadari bahwa mereka akan menghadapi pembahasan baru, sehingga mereka harus terfokus pada yang baru tersebut agar bisa memahami hal yang baru itu. Anak didik diharapkan akan berpikir apakah yang baru ada kaitannya dengan yang lama atau tidak tentunya setelah mendengar dan melakukan diskusi atau pembahasan.

\section{Prinsip Pembelajaran Bahasa}

Prinsip pembelajaran bahasa untuk anak usia dini adalah interaksi aktif. Ada tiga hal penting yang menjadi sumber pembelajaran bahasa/bagi anak di kelas, yaitu anak, orang dewasa, dan lingkungan. ${ }^{7}$

${ }^{7}$ Zahroh. 2002. Komunikasi dalam Pengasuhan. Kementerian Pendidikan dan Kebudayaan

\section{a. Anak}

Anak perlu dirangsang untuk dapat saling bercakap-cakap satu dengan yang lainnya. Dengan interaksi aktif antar anak, maka bahasa anak akan berkembang dengan cepat. Karena itu di lembaga PAUD perlu rnenggabungkan anak dari berbagai usia. Harapannya adalah anak yang lebih tua dapat mencontohkan bahasa yang Iebih kaya kepada anak yang Iebih muda, demikian sebaliknya anak yang Iebih muda akan banyak belajar dari anak yang Iebih tua.

\section{a. Orang Dewasa (Tutor/Pendidik)}

Orang dewasa yang hanya diam di dalam kelas kurang mendukung perkembangan bahasa anak. Segala sesuatu yang dilakukan anak dapat diperkuat o!eh pendidik dengan ucapan-ucapan yang menggali kemarnpuan berpikir anak Iebih tinggi yang tentunya akan terucap melalui percakapannya dengan pendidik. Pendidik menggali dengan pertanyaan-pertanyaan terbuka sehingga anak dapat berpikir aktif. Karena itu perlu pendidik yang aktif akan memberikan pengalaman pada anak dalarn menggunakan bahasa yang tepat. Pendidik juga perlu rnengucapkan kalimat dengan bahasa yang benar. Jika orang dewasa memberikan contoh katakata yang keliru, maka anak akan meniru kata-kata tersebut.

Berikut ini beberapa hal yang perlu diperhatikan oleh orang dewasa untuk memfasilitasi pembelajaran bahasa anak, antara lain:

1. Pembelajaran bahasa bagi anak-anak menjadi mudah apabilamereka memiliki lingkungan dan stimulasi yang tepat.

2. Bayi belajar dan mendapat ide untuk "bicara" dari mendengarorang-orang disekitarnya bercakap-cakap. Oleh karena itu, saat beraktivitas dengan bayi upayakan untuk selalu mengatakan apa yang kita lakukan, seperti: "Ayo ganti popok dulu. Wah popoknya basah. Ibu ambil popoknya, dibersihkan dulu ya pakai air, sekarang dilap, nah baru pakai popok yang bersih. sudah selesai".

3. Anak siap belajar untuk membuat suara dari bahasa yang ia pelajari. Bila seorang anak hidup dalam lingkungan dimana dua bahasa dipakai maka ia akan dapat membunyikan suara kedua bahasa tersebut. Seperti suara mobil dan bina- 
tang, ini dapatmembantu meningkatkan kemampuan mendengar anak.

4. Pertama-tama kita harus menjadi pendengar yang baik.Bicaralah sebanyak mungkin dengan bayi dan mencobamembuat percakapan pribadi dengan mereka. Usahakan agaranak melihat bahasa tubuh anda.

5. Biarkan anak memahami perkataan dan perasaan kita dengan cara mencocokkan apa yang kita katakan dengan apa yang kitalakukan atau yang kita katakan dengan ekspresi wajah kita.

6. Sangatlah penting untuk mengaitkan antara perkembangan bahasa dengan perkembangan lingkungan dan sosial anak-anak Kurikulum seharusnya diletakkan pada kerangka budaya.

7. Pendidik terlampau sering membuat setting belajar untuk anakusia dini terkesan mirip “sekolah". Akibatnya banyak pendidikterdorong mulai mengajarkan membaca, menulis, berhitung danaspek formal lain dari pembelajaran. Sesungguhnya membelajarkan anak usia dini memerlukan waktu lebih lama sampai anak siap menerima.

8. Belajar membaca dan menulis akan terserap jauh Iebih cepat dan efektif oleh anak-anak yang sudah memiliki latar belakang pemaharnan dan kemampuan verbal. Contohnya ditambahkan seperti apa pemahaman dan kemampuan verbal itu. Untuk menambah kosa-kata anak, pendidik harus menggunakan kata-kata tersebut secara ekspresif. Penggunaan kosakata baru sebaiknya dilakukan berulangkali. Dan kata-kata tersebut hendaknya bermakna dan menyentuh perasaan anak-anak sehinggatidak mudah dilupakan.

9. Bergembiralah dalam membawakan lagu anak denganberekpresi sesuai dengan irama.

10. Dengarkan apabila anak sedang berbicara sampai selesai baru kemudian tanggapi.

\section{b. Lingkungan}

Lingkungan tempat anak itu berada juga harus merupakan lingkungan yang aktif, yaitu lingkungan yang kaya dengan bahasa. Orang dewasa bisa meletakkan banyak kata di lingkungan bermain anak. Di mana-mana anak dapat melihat tulisan sehingga menolong anak dalam mempelajari keaksaraan. Misalnya : kalau ada meja, dapat diberi tulisan "m e j a,, dll. Pendidik yang aktif akan membawa lingkungan di luar anak yang kaya dengan bahasa ke dalam pikiran anak dan juga mengeluarkan segala sesuatu yang ada di dalam pikiran anak ke luar melalui bahasa yang diucapkan anak. Dengan dernikian pengetahuan anak akan terus bertambah.

Selain tiga hal penting diatas, berikut ini adalah beberapa faktor yang dapat mempengaruhi perkembangan bahasa dan mendorong percepatan dalam pemerolehan bahasanya, yaitu :

1. Anak berada di dalam lingkungan yang positif dan bebas dari tekanan. Anak selalu dibiasakan untuk ikut dalam pembicaraan. Bila ada benda yang dibicarakan orang tua dapat menunjuk dan menyebutkan nama benda itu. (sebagaimana disebutkan di atas, bahwa lingkungan yang kaya bahasa akan menstimulasi perkembangan bahasa anak. Stimulasi tersebut akan optimal jika anak tidak merasa tertekan.

2. Pandang mata anak saat berbicara. Kontak tersebut mendorong anak aktif berbicara, Menunjukkan sikap dan minat yang tulus pada anak.Anak usia dini emosinya masih kuat, karena itu pendidik harus menunjukkan minat dan perhatian tinggi kepada anak. Orang dewasa perlu merespon anak dengan tulus

3. Menyampaikan pesan verbal diikuti dengan pesan non verbal. Dalam bercakap-cakap dengan anak, orang dewasa perlu menunjukkan ekspresi yang sesuai dengan ucapannya. Perlu diikuti gerakan, mimik muka, dan intonasi yang sesuai.

4. Melibatkan anak dalam komunikasi.Orang dewasa perlu melibatkan anak untuk ikut membangun komunikasi. Kita menghargai ide-idenya dan rnemberikan respon yang baik terhadap bahasa anak.

5. Gunakan ejaan yang benar. Hindari ejaan yang dibuat-buat.

6. Bicarakan apa yang benar-benar dilakukan dan dialami anak.

7. Beri respon yang lebih banyak atas pertanyaan anak.

8. Gunakan tata bahasa yang benar dalam berbicara. Hal ini penting karena anak peniru yang unggul. Ia akan terbiasa dengan percakapan sehari-hari.

9. Betulkan kesalahan bahasa anak dengan lembut, baik dalam pengucapan mapun susunan.

10. Hindari memaksa anak untuk menghafal kata. Sebenarnya anak suka mengulang-ulang kata 
yang baru dikenal. Orang tua dapat mendukung aktivitas ini. Tetapi, bila anak enggan orang tua tidak perlu mendorong lagi.

\section{Kesimpulan}

Perkembangan bahasa anak adalah pemahaman dan komunikasi melalui kata, ujaran, dan tulisan. Pemahaman kata yang dikomuniasikan melalui ujaran ujudnya mendengarkan dan berbicara. Pemahaman kata yang dikomunikasi dalam bentuk tulisan ujudnya membaca dan menulis. Dengan demikian perkembangan bahasa meliputi kemampuan mendengarkan berbicara, menulis dan membaca.strategi komunikasi terhadap anak usia dini adalah Komunikasi Efektif, komunikasi efektif adalah adanya saling memahami apa yang dimaksud oleh si pemberi pesan dan yang menerima pesan. Kajian komunikasi lisan sebagai bagian dari pembicaraan yang menitikberatkan pada pengucapan. Pada dasarnya, apa yang dikomunikasikan dalam bentuk lisan harus tersampaikan pesannya secara akurat, dengan memperhatikan tiga hal yang sangat urgen yaitu penggunaan istilah yang tepat, berkesinambungan, dan adanya aba-aba atau sinyal ketika akan berpindah tema.

\section{Daftar Pustaka}

Akhadiah, Sabarti. 1991. Bahasa Indonesia I, Jakarta: Depdikbud.

Brown, H. Douglas. 1994. Principles of Language Learning and Teaching. Third Edition. New Jersey : Prentice Hall Regents.

Burn, A, \& Joyce, H. 1997.Focus on Speaking. Sydney: Sydney National Centre for English Language Teaching and Research

Direktorat PADU. 2002. Buletin PADU Jurnal Ilmiah Anak Dini Usia Edisi 02. Jakarta.

Direktorat PADU. 2002. Modul Pelatihan Pengelola dan Tenaga Pendidik Kelompok Bermain. Jakarta.

Hurlock ,Elizabeth B.. 2005. Perkembangan Anak Jilid 1. Jakarta. Penerbit Erlangga.

Hurlock, Elizabeth B. 1978. Perkembangan Anak Jilid 2. Erlangga. Jakarta.

Kartono, Kartini. 1995. Psikologi Anak (Psikologi Perkembangan). Mandar Maju. Bandung.

William Sears.2006. The Succesful Child..Penerjemah; Tim Embun.Jakarta.

Zahroh, Iroh Siti. 2002 .Komunikasi dalam Pengasuhan.Dirjen PAUD Nonformal dan Informal. Kementerian Pendidikan dan Kebudayaan 
57 NUANSA Vol. XI, No. 1, Juni 2018

Husnul B ahri| Strategi Komunikasi Terhadap Anak Usia Dini 57 